\title{
ANNALS
}

OF THE

\section{SOUTH AFRICAN MUSEUM.}

(Vol. X.)

\section{1.-On some South African Dermaptera (Earwigs) in the South African Museum, Cape Town.-By Malcolm Burr, D.Sc., F.Z.S., F.L.S., F.E.S., F.G.S.}

Dr. Louis Péringuey, of the South African Museum, Cape Town, has kindly communicated to me a small box of earwigs from South Africa. The collection contains twenty-two species, of which seven are new. If we exclude three from Rhodesia, there remain seven new out of nineteen from South Africa alone. This is a very high proportion, and should be an incentive to further collecting in a district which has not yet been worked for Dermaptera. And out of the nineteen known species, two were sent to Europe by Mr. Péringuey some years ago, and described by de Bormans, which have not been taken since, and, logically speaking, belong to the same collection.

It is noteworthy that of the new species one is referred to Apterygida, Westw., which, as now reduced, contains only its type, the common Mid-European A. albipennis, Meg. One is referred to Chelidurella and two others to Mesochelidura, at least until this group is rearranged, and both these are essentially Palearctic genera.

A new genus is required for the two new Brachylabina, a curious and interesting group, represented by isolated species throughout the tropical world.

Of the two described by de Bormans, one is also referred to Mesochelidura, but the other to Esphalmemus, a genus which is 
otherwise only represented in South America from Patagonia to. Ecuador.

It is exceedingly probable that if earwigs are systematically collected in South Africa a number of further new species will be discovered, and I shall be most grateful to any naturalists, especially those who live in or near mountainous districts, who will save and send me any earwigs that they come across. They will be encouraged by the probability of discovering species new to science.

\section{FAMILY APACHYID E.}

Gen. APACHYUS, Serville.

1. A. murrayi, Dohrn, var. Reichardi, Karsch. Apachya murrayi, Dohrn, Stett. ent. Zeit., xxiv., p. 44 (1863). Apachya reichardi, Karsch, Berl. ent. Zeit., xxx., p. 85 (1886). Beira : 1 ð, P. A. Sheppard, 1905.

This species is widely distributed throughout Central Africa.

\section{FAMILY PYGIDICRANIDÆ.}

1. Sp. n.

Gen. DICRANA, Burr.

Cape Colony: Port St. John, 1 \&.

This is a short-winged form, probably new, but I am unable to describe it without the male.

Gen. PICRAnIA, Burr.

1. P. Liturata, Stål.

Forficesila liturata, Stål, Öfv. Vet. Ak. Förh., xii., p. 347 (1855).

Natal: Eshowe, 1887, 1 ․

Cape Colony: Touw's River, W. J. Purcell, 1 larva.

This species is rare in collections and museums; it is restricted to South Africa, as the one in the Paris Museum recorded by me under this name from Diego Suarez is probably distinct.

\section{FAMILY KARSCHIELLID $Æ$.}

Gen. BORMANSIA, Verhoeff.

1. B. Meridionalis, Burr.

Bormansia meridionalis, Burr, apud Distant, Insecta Transvaalensia, Appendix. Orth., part v., p. 97, fig. 13 (1904). 
Southern Rhodesia: Insiza, 1 o .

Hitherto only known from the type, from Zoutpansberg, now in the British Museum.

\section{FAMILy LABIDURID $Æ$.}

\section{Sub-Family ECHINOSOMATIN $Æ$.}

Gen. ECHInOSOMA, Serville.

1. E. Wahlbergi, Dohrn.

Echinosoma wahlbergi, Dohrn, Stett. ent. Zeit., xxiv., p. 64 (1863).

Natal: Durban, 1 б.

Cape Colony : Cape Town, 2 larvæ, L. Péringuey, 1887.

A species widely distributed throughout Africa.

\section{Sub-FAMILY ESPHALMENIN Æ.}

Gen. ESPHALMenUs, Burr.
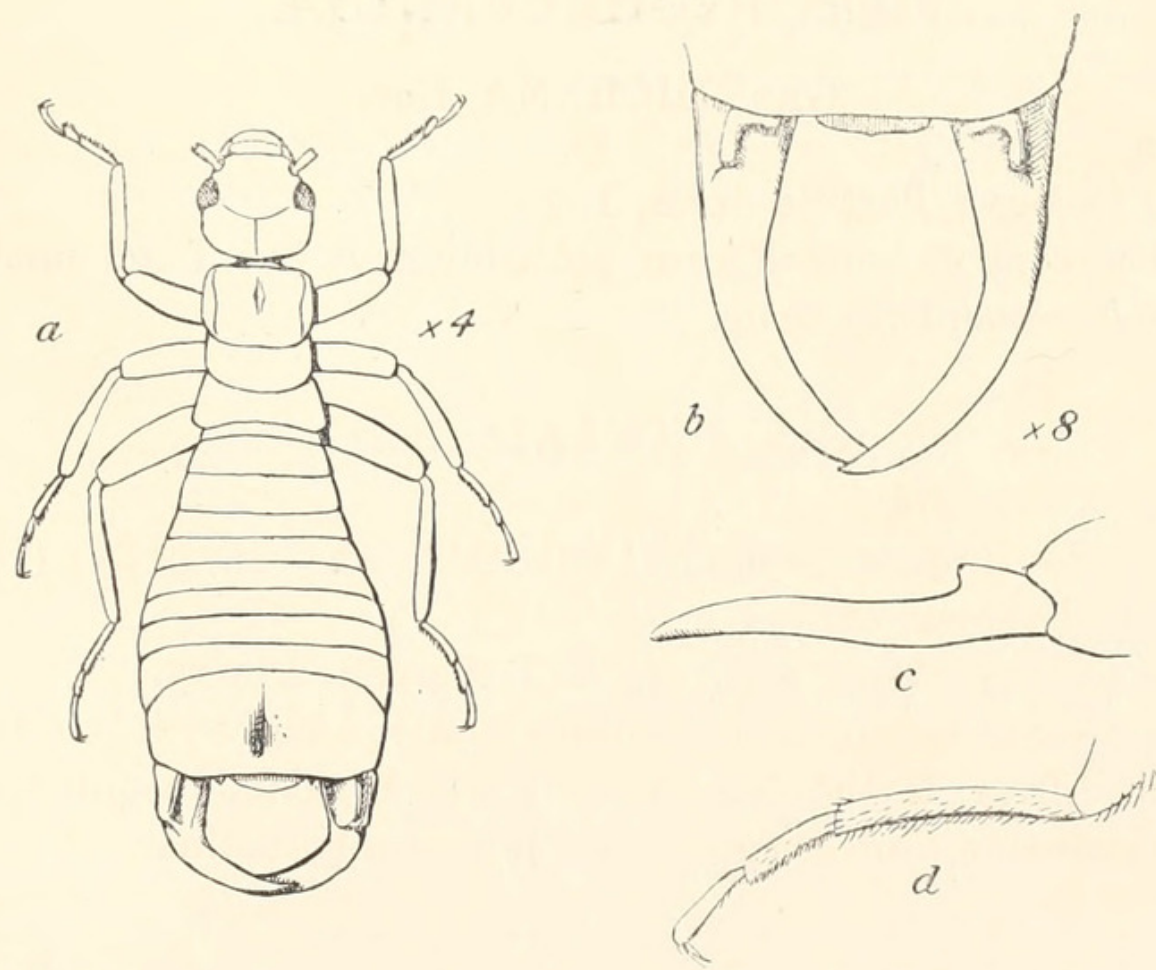

FIG. 1.-(a) E. péringueyi ; $(b)$ forceps $\delta ;(c)$ forceps, side view ; (d) tarsus, side view.

1. E. péringueyi, Borm. (Fig. $1, a-d$ ).

Gonälabis peringueyi, Bormans, Ann. Mus. Civ. Gen. (2), xx. p. 451 (1900). 


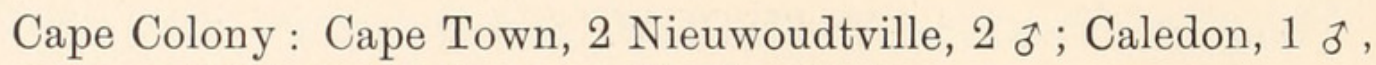
June, 1887, L. Péringuey ; Dunbrody, 1 శ.

Hitherto only known from de Bormans' type and syntypes, from Caledon, Cape Colony.

\section{Sub-Family LABIDURIN $Æ$.}

Gen. LABIDURA, Leach.

1. L. Riparia, Pall.

Forficula riparia, Pallas, Reise russ., ii., Anhang., p. 727 (1773). Recorded from numerous places in Cape Colony, Orange River Colony, Transvaal, and Rhodesia.

A cosmopolitan species.

\section{Gen. NALA, Zacher.}

1. N. Lividipes, Duf.

F'orficula lividipes, Dufour, Ann. Sci. Nat., xiii., p. 340 (1828).

Echinosoma obscurum (Kirby, Ins. Transvaalensia, Orth., p. 12 Labidura indistincta $\}$ (1900).

Bechuanaland: Vryburg, 2 శో, 5 \& , Jones, 1904.

Found throughout the Old World. South African specimens of this species were described by Kirby under the names of Echinosoma obscurum and Labidura indistincta.

\section{Sub-FAmily BRACHYLABIN $Æ$.}

\section{Gen. CTENISOLABIS, Verhoeff.}

1. C. togoensis, Verhoeff.

C. togoensis, Verhoeff, S. B. ges. Naturf. Fr. Berlin, No. 1, p. 14 (1901).

Cape Colony: Dunbrody, 3 \&, 1 larva.

These specimens are undoubtedly referable to Ctenisolabis, and I refer them provisionally to the only known African species, $C$. togoensis. But these small, rare, apterous earwigs are probably restricted in distribution, and it is very likely that these specimens from Cape Colony are distinct from Verhoeff's species from Togo. But it is impossible to draw good specific distinstions from Verhoeff's description alone, and a careful comparison of authentic specimens is necessary in order to establish the identity or distinction. 


\section{ANTISOLABIS, n. g.}

Oculi parvi, anteriores; elytra omnino desunt; mesonotum haud carinatum; antennæ segmentis sat longis, haud globularibus.

Entirely apterous; eyes small, normal ; mesonotum not keeled; antennæ with segments relatively long, cylindrical, not globular.

This genus stands in the same relation to Nannisolabis that Isolabis stands to Leptisolabis; it agrees in the non-keeled mesonotum, but differs in the relatively long and cylindrical antennal segments.

Type: A. myrmecoides, Burr.

Antisolabis myrmecoides, sp. n.

Fig. 2, $a-c$.

Parva, atra ; antennæ segmentis 15 , cylindricis ; pronotum transversum, postice paullo ampliatum; thorax linea media rufa. ornatus; caput nitidum; abdomen innitidum.

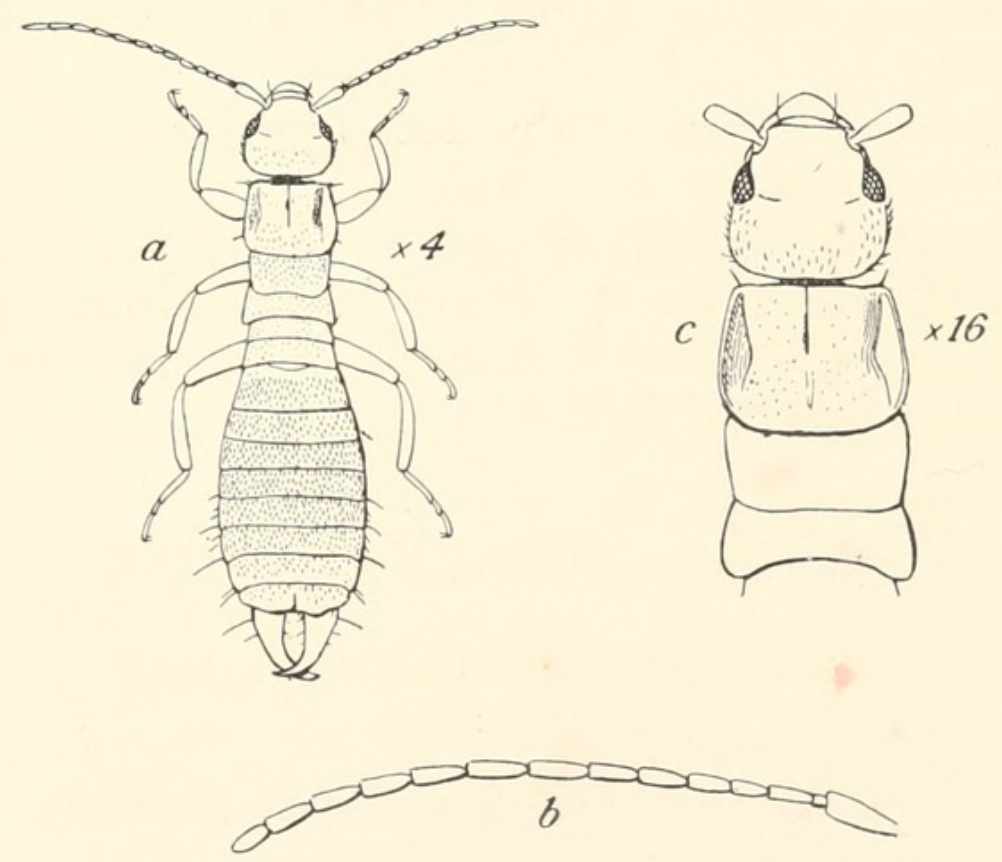

FIG. 2.-(a) A. myrmecoides $\delta ;(b)$ antenna; $(c)$ head and thorax.

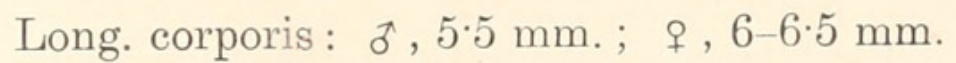

Long. forcipis : $\delta, 5 \mathrm{~mm}$; + , $5 \mathrm{~mm}$.

Small, black, with a fine pale pubescence.

Antennæ black, with 15 segments, all relatively long, cylindrical, not globular, fourth nearly as long as the third, which is about as long as the îrst, the fifth equal to the third. 
Head tumid, not pubescent, smooth, shining black; sutures obsolete; eyes small, anterior.

Pronotum sub-rectangular, a little broader than long, and gently widened posteriorly, the posterior angles rounded; black, with a median thin rufous line.

Mesonotum not keeled, rectangular, as also the-

Metanotum, which is feebly concave, with the median rufous line continued from the pronotum.

Legs black, the joints and tarsi yellowish; femora rather thick; tarsi slender and long, first and third segments equal, the second longer than broad.

Abdomen sub-parallel in the $q$, gently dilated in the $\delta$, dull black.

Forceps cylindrical, thick at the base and rapidly attenuate, gently curved, more strongly in the $z$ than in the $q$, sub-contiguous in the $\delta$, contiguous in the $q$.

Cape Colony : Caledon, 2 ठ, 6 q.

This black little species has a superficial resemblance to an ant. The dull black body, with median rufous line on the thoracic plates, and the smooth shining jet-black head, make it easily recognisable.

\section{Antisolabis sulcatipes, sp. n.}

Fig. 3, $a-d$.

Statura majore; colore fusco-brunneo; corpus sublæve, minutissime punctulatum; pronotum longius quam latius, postice ampliatum; pedes longi; tibiæ utrinque sulcatæ; tarsi segmento tertio quam primum breviori, quam secundum vix breviori.

Long. corporis : $\uparrow, 12 \mathrm{~mm}$.

Long. forcipis : $\uparrow, 2 \mathrm{~mm}$.

Size relatively large, general colour dull, dark brown, body nearly smooth, very finely punctulate.

Antennæ with 15 segments, cylindrical and relatively long, fourth longer than broad; the apical segments passing to ovate; brown, the apical three or four whitish.

Head smooth; sutures obsolete; eyes normal.

Pronotum longer than broad, gently widened posteriorly, the posterior angles rounded, sides strongly reflexed.

Mesonotum smooth, not keeled.

Metanotum similar, concave posteriorly.

Legs long and slender, the tibiæ compressed, with a narrow longi- 
tudinal shallow furrow or sulcus down each side; tarsi long and slender, the third segment about one-third and shorter than the first, the second more than half as long as the third.
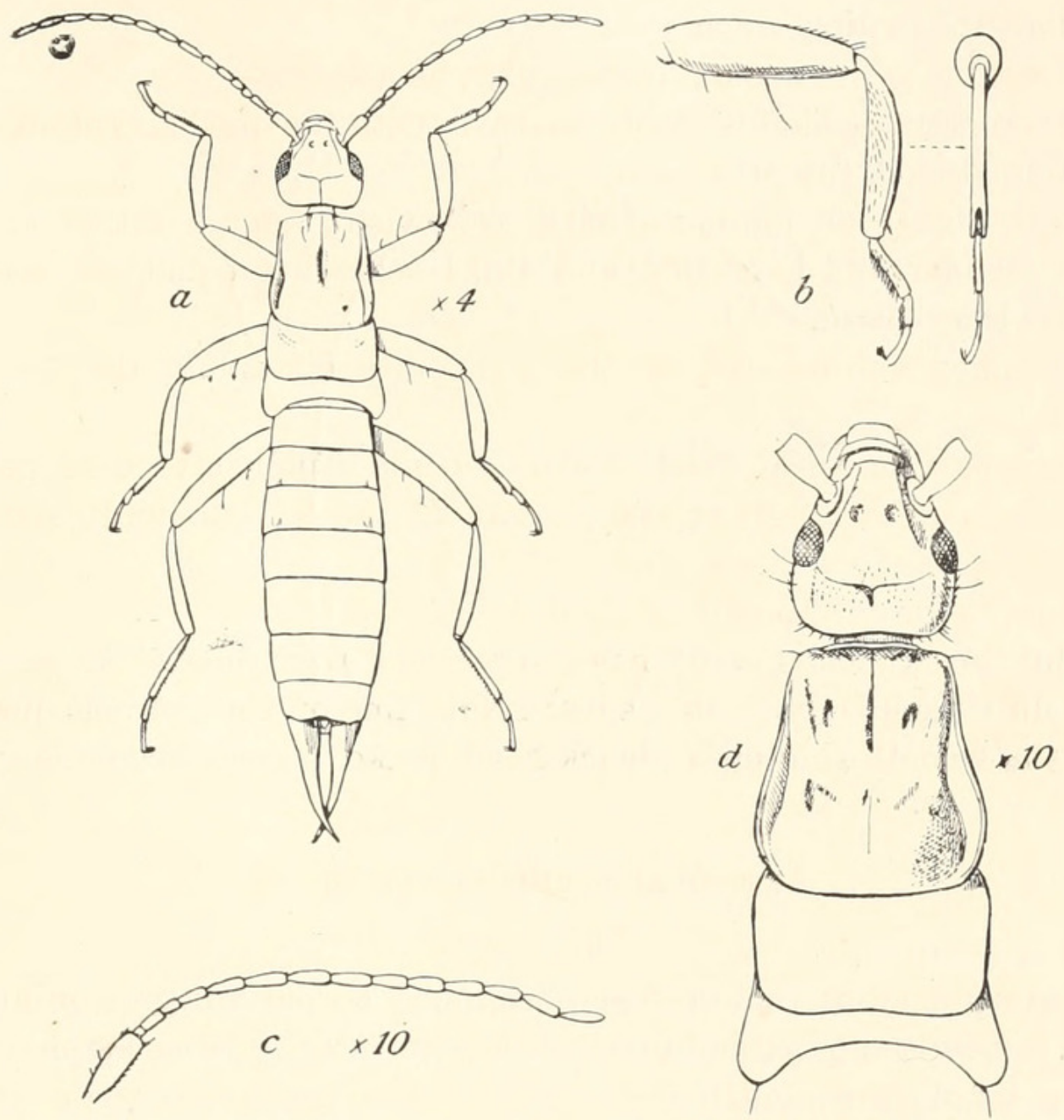

FIG. 3.-(a) A. sulcatipes $\delta ;(b)$ leg; $(c)$ antenna ; $(d)$ head and thorax.

Abdomen smooth, brown.

Forceps typical, but rather long and slender.

Cape Colony: Cape Town, 1 q.

This is so well marked a species that I describe it on a single female, as in this group there is but little difference between the sexes.

It is well characterised, among other things, by the furrow on the tibiæ.

\section{FAMILY LABIID $Æ$.}

1. L. MINOR, Linn.

Gen. LABIA, Leach.

Forficula minor, Linn., Syst. Nat., ed. x., i., p. 423 (1758). 
Cape Colony: Stellenbosch, 3 $ぇ, 5$ †, November, 1887, L. Péringuey.

A native of the Palearctic Region. This species is found in Africa from Somaliland to the Congo and Cape Colony; it is now firmly established in North America.

2. L. Marginalis, Thunb.

Forficula marginalis, Thunberg, Acta Soc. Upsal, ix., p. 52 (1827).

Transvaal: Pietersburg, Shilouvane, 1 .

Delagoa Bay : 1 q, L. De Coster, 1889.

Widely distributed throughout Africa.

Gen. SPHINGOLABIS, Bormans.

1. S. villica, sp. n.

Fig. $4, a-b$.

Statura sat forti; caput et pronotum fulvo-rufa; elytra alæque nigræ, abdomen nigrum, pedes flavi; pygidium acuminatum; forcipis bracchia of valida, elongata ac depressa, ante apicem dente forti armata.

Long. corporis: $\precsim, 7.5 \mathrm{~mm}$.

Long. forcipis : $\delta, 2.5 \mathrm{~mm}$.

Size medium.

Antennæ with 13 segments, pyriform or sub-conical, the third quite short, the fourth and fifth each quite as long as, or longer than, the third, dark brown.

Head brick-red, rather broad, tumid posteriorly, and somewhat excavate posteriorly; eyes small, black.

Pronotum orange-yellow, as broad as long, anterior margin gently convex, sides straight, posterior margin rounded, tlat.

Elytra and wings ample, black, finely punctulate, with a dense close pubescence.

Legs yellow, the femora black at the base ; tarsi slender, first and third segments equally long and slender; femora rather thick.

Abdomen parallel-sided, passing from black at the base to deep red near the apex, covered with long reddish bristles.

Last dorsal segment transverse, rectangular, with a feeble depression in the middle of the posterior margin, and a faint tumid elevation on each side of it.

Forceps with the branches in the $\delta$ remote at the base, stout and rather broad, elongate, and nearly straight, depressed and sulculate 
above from base to apex; on the inner margin in the apical third there is a strong sharp tooth; the points are hooked; the whole forceps are deep red in colour and covered with long pale bristles.

Cape Colony: Dunbrody, August 5, 1901, 1 ठ .
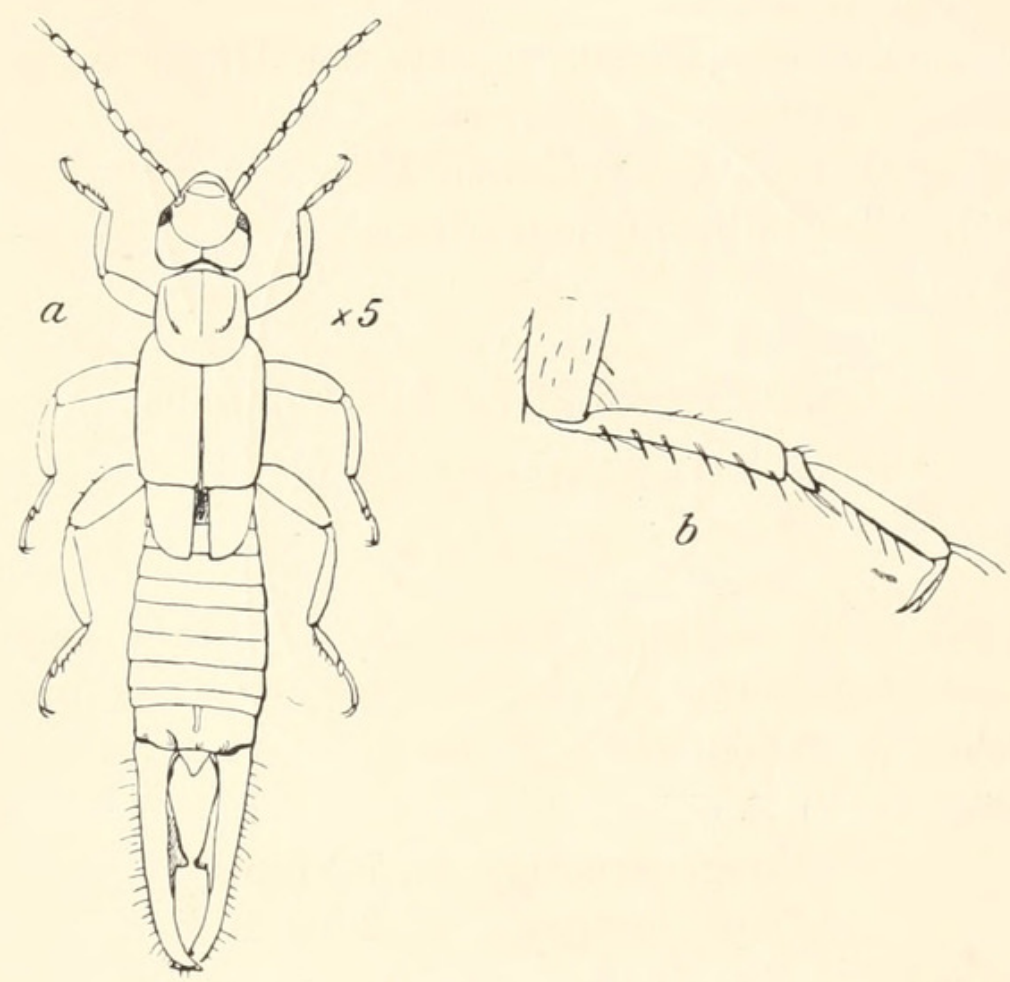

FIG. 4.-(a) S. villica o type; $(b)$ tarsus.

The coloration and form of the pygidium and forceps of this species render it easily recognisable. After a good deal of hesitation I place it in the genus Sphingolabis, Borm., revived for its type S. furcifer, Borm., S hawaïensis, Borm., only; these are really nothing more or less than rather large and relatively robust Chatospanias, and closely related to Labia.

\section{FAMILY FORFICULID $Æ$.}

\section{Sub-FAmily CHELIDURIN $Æ$.}

Gen. MESOCHELIDURA, Verhoeff.

1. M. PÉRINGueyi, Burr (Fig. 5, $a-b$ ).

Chelidura péringueyi, Burr, Ann. Mag. N. H. (7), xi., p. 275 (1902). 
Cape Colony: Stellenbosch, 4 б, 5 , 3 larvæ; Cape Town, 3 б , 4 ; Table Mountain, 1 o , var. forcipata; Houw Hoek, 1 ठ.

Only known from Cape Colony.

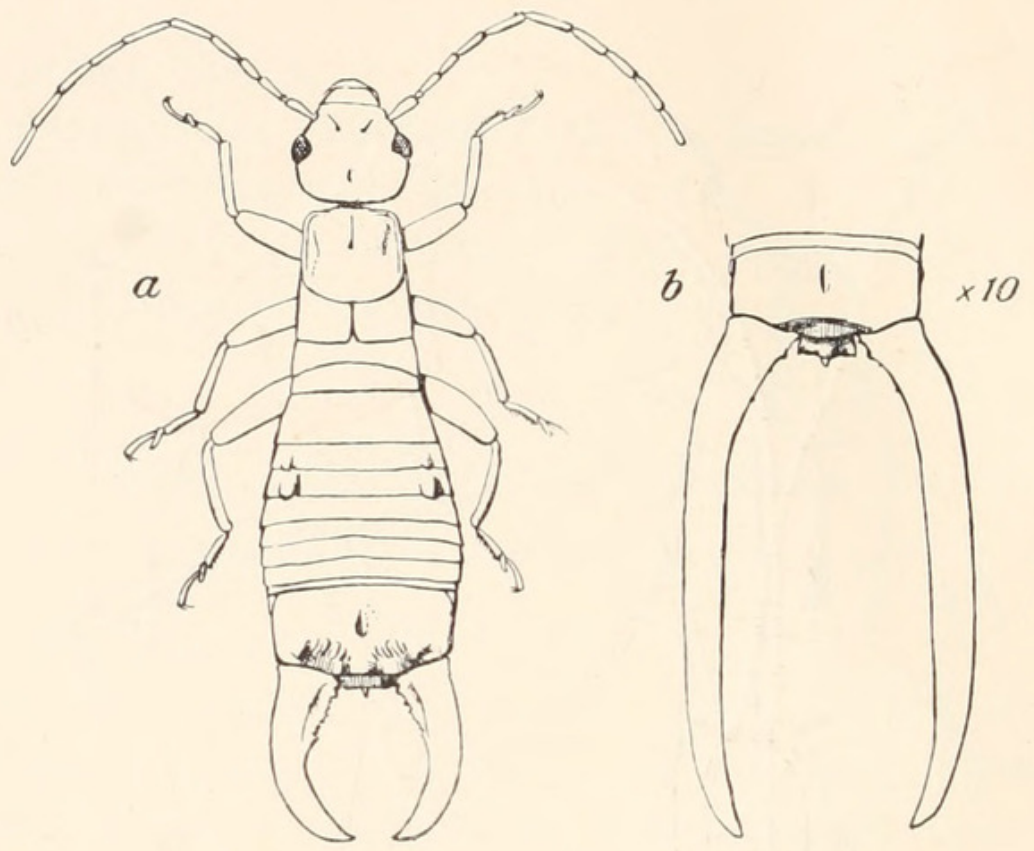

Fig. 5.-(a) M. péringueyi o form cyclolabia; $(b)$ forceps $\delta$ form macrolabia.

2. M. PRoMontoriI, sp. n.

Fig. $6, a-b$.

Statura gracili; pygidium o truncatum, integrum; forcipis bracchia $\delta$ basi remota, gracilia, sensim arcuata.

Long. corporis : ठ , $9 \mathrm{~mm}$; ; , $8 \mathrm{~mm}$.

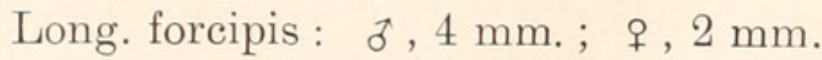

Size median, build slender, general colour yellowish brown.

Antennæ red-brown, paler at the base and darker at the apex, with 12 segments, fourth a little shorter than the third, all very slightly thickened at the apex.

Head smooth, dull red, tumid; sutures obsolete.

Pronotum rectangular, transverse, all sides straight, depressed.

Elytra rudimentary, meeting at the suture, but exposing a short portion of the mesonotum and all the metanotum.

Legs yellowish, slender, first tarsal segment slightly longer than the third.

Abdomen very feebly widened posteriorly in the $\widetilde{\sigma}$, and gently narrowed there in the $q$, deep red-brown. 
Last dorsal segment transverse in the $\delta$, the posterior margin raised into a low, rugulose ridge, beyond which the surface slopes down to the pygidium; in the of simple, narrow.

Penultimate ventral segment $\delta$ broadly rounded.

Pygidium $\delta$ an obtuse tubercle, with face vertical and lower

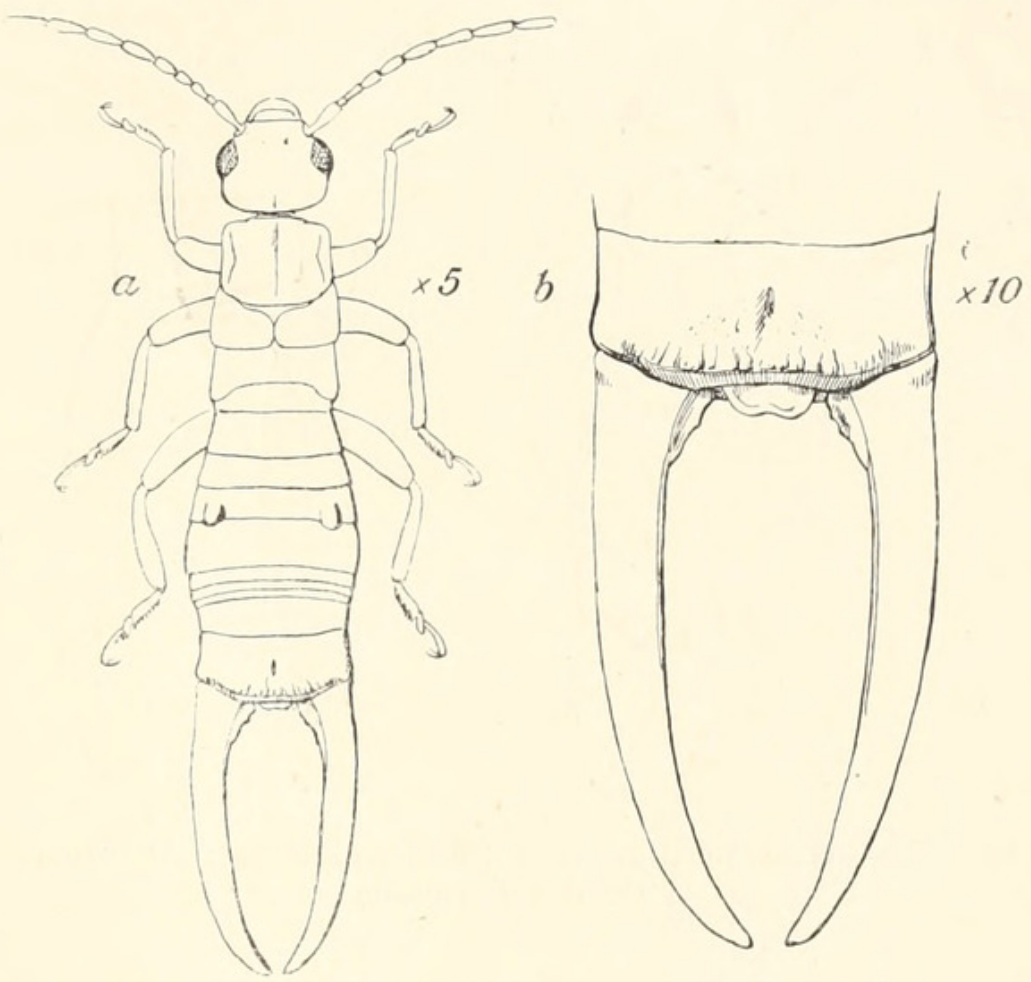

FIG. 6.-(a) M. promontorii $\delta$ type; $(b)$ forceps $\delta$.

margin produced into a narrow flat transverse lobe, with converging sides and truncate apically; in $q$ minute.

Forceps with the branches in the $\delta$ slender, remote at the base, gently arcuate, feebly dilated near the base, with an almost obsolete tooth near the apex; in the $q$ simple, straight and sub-contiguous.

Cape Colony: Caledon, of o , L. Péringuey, 1905.

This species has a close superficial resemblance to the European Apterygida albipennis, which goes even down to the forceps, but the pygidium is not quite the same, and the rudimentary elytra at once distinguish it.

3. M. KAFFIR, sp. n.

Fig. $7, a-b$.

Elytris valde rudimentariis, ad suturam non attingentibus; pygidium of $q$ emarginatum, lobis acutis; forcipis bracchia of remota, gracilia.

Long. corporis : ठ , $8.5 \mathrm{~mm}$.

Long. forcipis: $\delta, 3.5 \mathrm{~mm}$. 
Build slender; general colour yellowish and reddish brown.

Antennæ dark brown, with 12 segments, all cylindrical, the fourth a little shorter than the third.

Head ferruginous, smooth; sutures obsolete.

Pronotum yellowish brown, rectangular, transverse, depressed.

Elytra present merely as small lateral flaps, exposing the greater part of the mesonotum and all the metanotum, which are of the same colour as the pronotum.

Legs dirty yellow; tarsi slender, first and third segments about equally long.

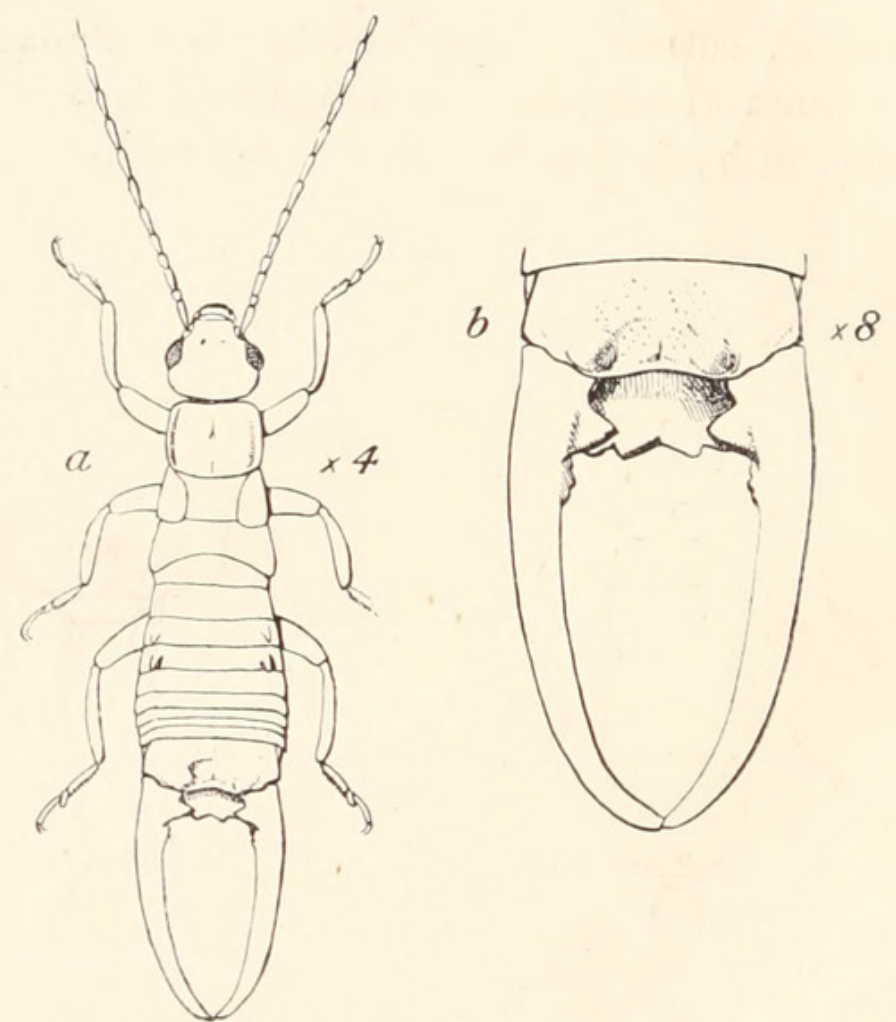

FIG. 7.-(a) M. kaffir $\delta$; (b) forceps $\delta$.

Abdomen yellowish ferruginous, passing to deep red-brown apically, and gradually dilated towards the apex.

Last dorsal segment transverse, with an irregular median depression and tumid, obtuse tubercle on each side.

Penultimate ventral segment broadly rounded.

Pygidium depressed, broad, like a slightly upturned plate, with a broad triangular emargination and triangular lobe on each side.

Forceps with the branches remote, slender, cylindrical, gently arcuate, with a strong, triangular laminate tooth on the inner margin at the extreme base.

Cape Colony: Dunbrody, 1 శै, January 14, 1903.

This species is well characteristic by the emarginate pygidium, 
with triangular lobes; it has a superficial resemblance to Apterygida, A. colonice, and M. promontorii. The elytra are reduced to mere lateral flaps (as in Euborellia stäli and E. moesta), and. on this account a new genus will be required for its reception.

The $q$ is unknown.

\section{Gen. CHELIDURELLA, Verhoeff}

\section{C. PURCelli, sp. n.}

Fig. $8, a-b$.

Statura minore ; corpus ad basin abdominis sub-dilatatum, apicem versus sensim angustatum; forcipis bracchia of basi remota, gracilia, sensim arcuata, ad basin margine interno laminato.

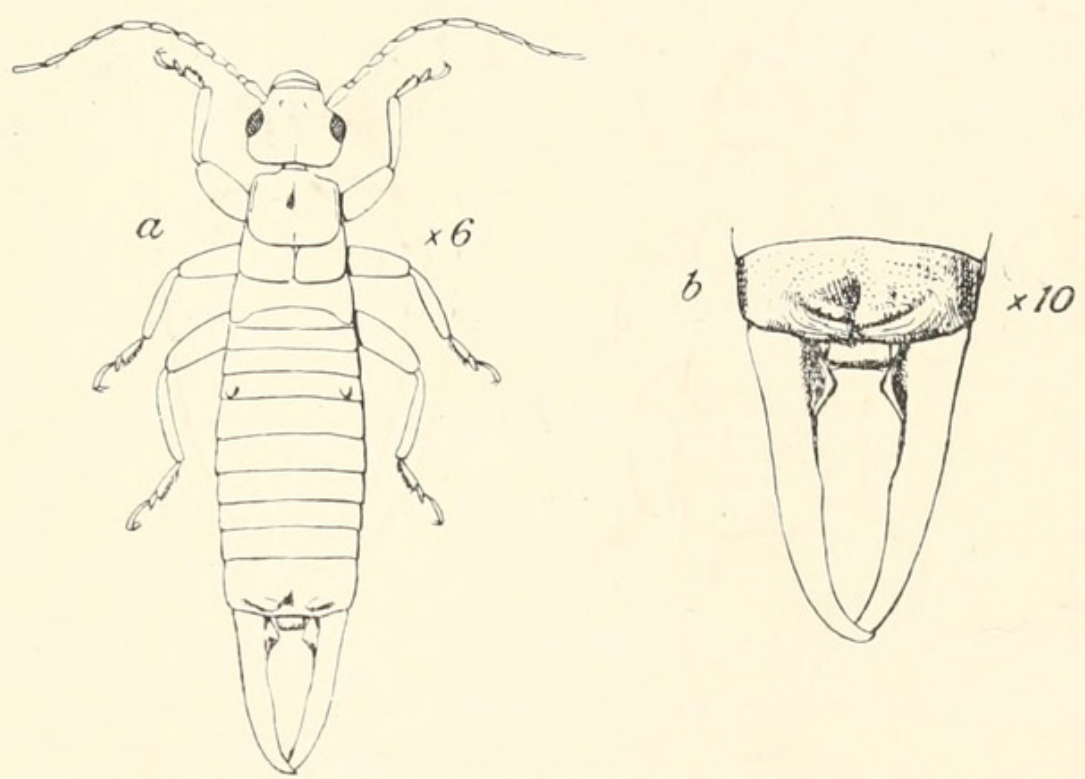

FIG. 8.-(a) C. purcelli o type; (b) forceps o

Long. corporis : ๙, $7.5 \mathrm{~mm}$.

Long. forcipis: §, $7.5 \mathrm{~mm}$.

General colour yellow-brown.

Antennæe with 11 segments, yellowish brown, cylindrical, the fourth a little shorter and little thicker than the third.

Head red-brown, smooth, tumid; sutures obsolete.

Pronotum broad, trapezoidal, broadened posteriorly, sub-rectangular, all sides straight, depressed.

Elytra rudimentary, much shorter than broad, completely covering the mesonotum but exposing the concave mesonotum, yellowish brown. 
Legs yellowish, slender; tarsi short, the first segment hardly as long as the third.

Abdomen deep red-brown, widest at the base, gradually narrowing towards the apex, punctulate.

Last dorsal segment transverse, rectangular, punctulate, with a median sulcus, and with a feeble crested tubercle on each side.

Penultimate ventral segment broadly rounded.

Pygidium short and broad, truncate posteriorly.

Forceps with the branches remote, cylindrical, feebly arcuate, the inner margin produced with a laminate triangular tooth near the base.

Cape Colony: Oudtshoorn, 1 б, W. F. Purcell.

This is rather a remarkable species. It must be provisionally placed in Chelidurella, but it has no real resemblance to C. acanthopygia, the type of that genus. The whole body is spindle-shaped, being gently broaajened from the pronotum to the first or second abdominal segment, where the maximum width is attained, and then gradually narrowed to the apex.

\section{Sub-Family FORFICULIN $Æ$.}

Gen. APTERygidA, Westwood.

1. A. colonie, sp. n.

Fig. 9, $a-c$.

A. albipennis vicina; differt præcipæ pygidio o quadrato, forcipisque bracchiis basi dente forti armatis.

$$
\begin{aligned}
& \text { Long. corporis : } \widehat{\jmath}, 8-10.5 \mathrm{~mm} \text {. } \\
& \text { Long. forcipis : } \delta, 3-4 \mathrm{~mm} \text {. }
\end{aligned}
$$

Size rather small, general colour reddish testaceous.

Antennæ testaceous, with 12-13 segments, the third rather short, fourth a little longer, and the rest gradually longer, all cylindrical.

Head smooth and tumid; sutures obsolete, dark red-brown.

Pronotum quadrate, a trifle longer than broad and slightly widened posteriorly; prozona and metazona not separated, and testaceous.

Elytra testaceous, smooth, truncate apically, the axillary angle feeble, exposing a portion of the mesonotum.

Wings abortive.

Legs testaceous or pale yellow ; first tarsal segment about as long as second and third united, second with prominent lobes, third slender. 
Abdomen not hairy, sub-parallel, deep ferruginous red, darker apically than basally, the lateral pliciform tubercles black and prominent.

Last dorsal segment of quadrate, ample, smooth, with no median sulcus, but a deep triangular depression in the middle near the posterior margin, which is slightly incrassate and sinuous, being gently produced to form a short rounded lobe on each side of the middle line.

Penultimate ventral segment $\precsim$ ample, very obtusely rounded.

Pygidium ơ a square, depressed plate.
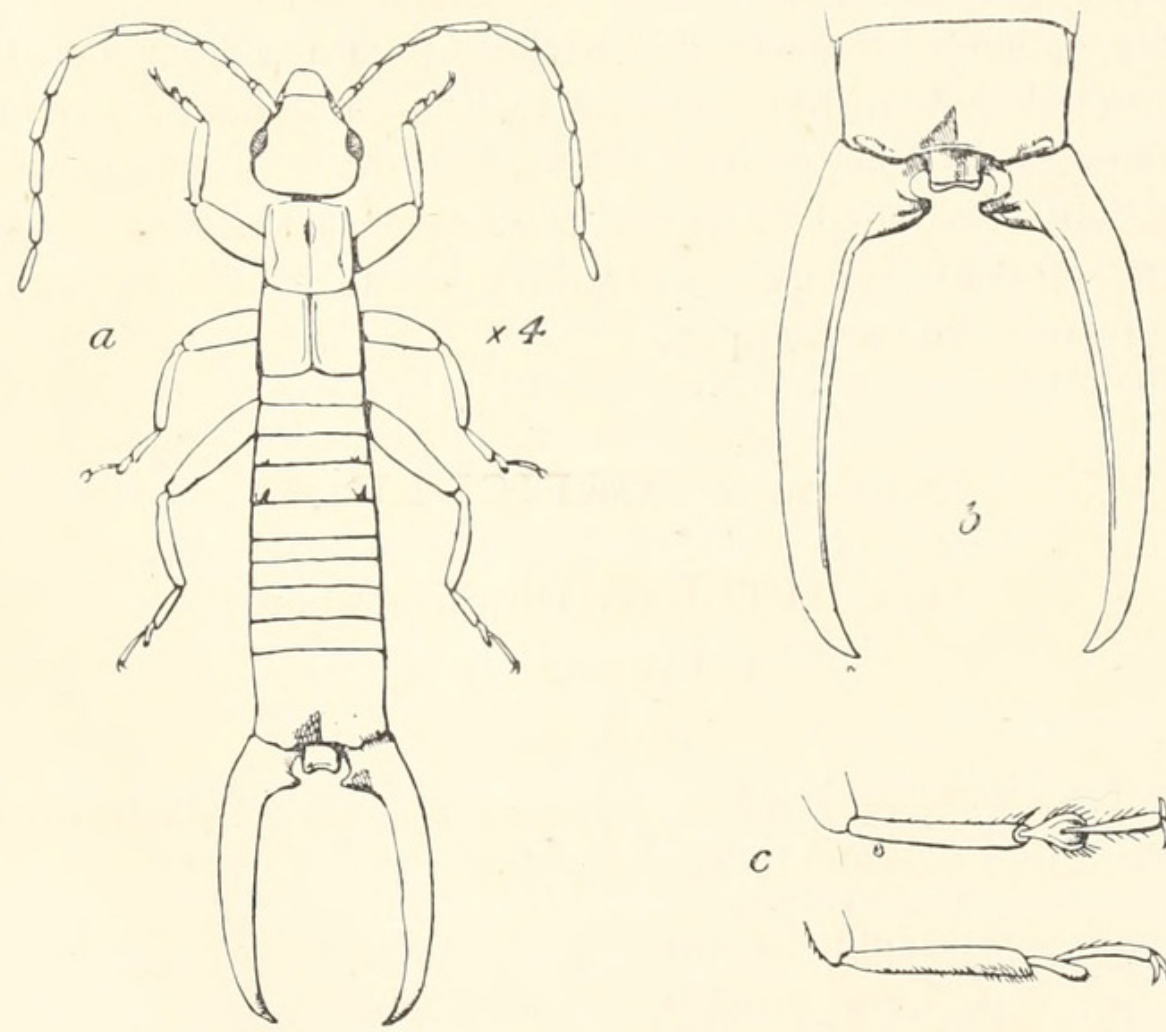

FIG. 9.-(a) A. coloniæ $\delta$ type; $b$ forceps; $(c)$ tarsus.

Forceps with the branches $\delta$ slender, remote at the base, rather elongate, slightly diverging at the base itself, then very gently arcuate, the tips black and feebly incurved; on the inner margin at the base there is a prominent, dilated, and depressed triangular tooth.

South Africa: 4 శ, Cape Town, August, 1887.

This species closely resembles the European A. albipennis, but the pronotum is longer and narrower, the pygidium more nearly square, and the strong basal tooth of the forceps is very distinctive. 
Gen. Elaunon, Burr.

1. E. erythrocephalus, Oliv.

Forficula erythrocephala, Oliver, Enc. méth., vi., p. 468 (1791).

Beira : 1 ठै, P. O. Sheppard, 1905.

Amatongaland: 1 \&, January, 1889.

Delagoa Bay: 4 б, 3 o, June, 1889, J. de Costa.

Cape Colony : Port St. John, 2 子, 1 $q$.

Distributed throughout the Ethiopian Region.

Gen. FORFICULA, L,

1. F. Senegalensis, Serv.

Forficula senegalensis, Serville, Orth., p. 39 (1839).

Griqualand: 1 o , var. forcipata, 1873.

Ovampoland: 1 ठ , 1890-1891, Erikson.

Southern Rhodesia: 1 , Salisbury; 1 q, Umtali.

Cape Colony: 1 q, Kowie River, Port Alfred; $1 \uparrow$, Port St. John ; 1 \&, Kentani, Dr. Kolbe.

Distributed throughout the Ethiopian Region.

\section{Sub-Family OPISTHOCOSMIIN $Æ$.}

Gen. Hypurgus, Burr.

1. H. micheli, Burr.

Opisthocosmia micheli, Burr, Tr. ent. Soc., London, p. 307 (1904). Southern Rhodesia: Umtali, 1 \% .

I cannot separate this specimen from $H$. micheli from Abyssinia, although it differs slightly in its brighter and more yellowish colour, especially of the elytra, which are somewhat longer, as the wings are perfectly developed. Probably it will eventually be discovered in intermediate localities. 


\section{INDEX.}

A.

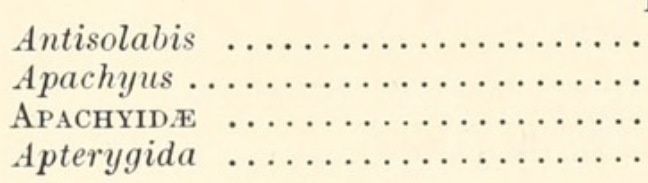

B.

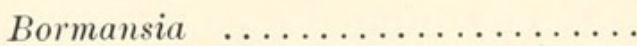

Brachylabinæ..................

C.

Chelidurella

Chelidurinæ $\ldots \ldots \ldots \ldots \ldots \ldots .9$

coloniæ (Apterygida) ............ 14

Ctenisolabis

D.

Dicrana

PAGE
5
2
2
14

2

4$$
\mathrm{N}
$$

$\ldots \ldots \ldots \ldots \ldots \ldots \ldots$

................... 4

$\mathrm{N}$.
Nala ..............
P. 


\section{$2 \mathrm{BHL}$ Biodiversity Heritage Library}

Burr, Malcolm. 1911. "On some South African Dermaptera (Earwigs) in the South African Museum, Cape Town." Annals of the South African Museum. Annale van die Suid-Afrikaanse Museum 10, 1-17. https://doi.org/10.5962/bhl.part.9310.

View This Item Online: https://www.biodiversitylibrary.org/item/17383

DOI: https://doi.org/10.5962/bhl.part.9310

Permalink: https://www.biodiversitylibrary.org/partpdf/9310

\section{Holding Institution}

MBLWHOI Library

\section{Sponsored by}

MBLWHOI Library

\section{Copyright \& Reuse}

Copyright Status: Public domain. The BHL considers that this work is no longer under copyright protection.

This document was created from content at the Biodiversity Heritage Library, the world's largest open access digital library for biodiversity literature and archives. Visit BHL at https://www.biodiversitylibrary.org. 